\title{
Serological evidence of Coxiella burnetii as a causative agent of culture negative infective endocarditis
}

\author{
Angelina Raghavendran*, Venkatasan Naveen Kumar, Gopalakrishnan Sathya Narayanan, Thangam Menon
}

From 2nd International Science Symposium on HIV and Infectious Diseases (HIV SCIENCE 2014)

Chennai, India. 30 January - 1 February 2014

\section{Background}

Culture negative infective endocarditis (CNIE) accounts for 2.5 to $31 \%$ of all cases of infective endocarditis and is responsible for delay in diagnosis and treatment with profound impact on clinical outcome. Coxiella burnetii is one of the important etiological agents of culture negative infective endocarditis. The present study was undertaken to determine the role of $C$ burnetii as an etiological agent in CNIE in South India.

\section{Methods}

Out of a total of 124 patients with CNIE during the period from 2008 to 2012, 46 were selected for the present study and stored serum samples were analysed by a qualitative ELISA to detect the IgG antibodies against $C$. burnetii using ELISA Kit (NovaTec Immundiagnostica GmbH, Germany).

\section{Results}

Among the 46 patients included in the study, 26 (57\%) were male and $20(43 \%)$ were female with mean age of 30 years in the range of 11-74 years. Out of the 46 patients screened for Phase I IgG class antibodies, 22 patients were found to be positive by ELISA. Among the 22 positive patients, majority of patients $(90 \%)$ had native valve endocarditis predominantly of the mitral valve $(60 \%)$. All the 22 patients presented with fever; about $64 \%$ of patients had rheumatic heart disease and $68 \%$ of them showed vegetation by echocardiography.

\section{Conclusions}

Screening of all CNIE patients for C. burnetii Phase I IgG antibodies will help in initiating appropriate treatment and in bringing down the case fatality rates in culture negative infective endocarditis in India.

Published: 27 May 2014

doi:10.1186/1471-2334-14-S3-P36

Cite this article as: Raghavendran et al: Serological evidence of Coxiella burnetii as a causative agent of culture negative infective endocarditis. BMC Infectious Diseases 2014 14(Suppl 3):P36.
* Correspondence: angeragh@yahoo.co.in

Department of Microbiology, Dr. ALM PG Institute of Basic Medical Sciences, University of Madras, Taramani, Chennai, Tamil Nadu, India
Submit your next manuscript to BioMed Central and take full advantage of:

- Convenient online submission

- Thorough peer review

- No space constraints or color figure charges

- Immediate publication on acceptance

- Inclusion in PubMed, CAS, Scopus and Google Scholar

- Research which is freely available for redistribution
() Biomed Central

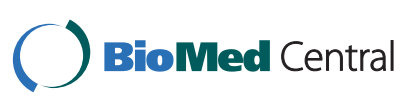

